\title{
A trophic bottleneck?: The ecological role of trout-perch Percopsis omiscomaycus in Saginaw Bay, Lake Huron
}

\author{
By C. E. Blouzdis ${ }^{1}$, L. N. Ivan ${ }^{1, *}$, S. A. Pothoven ${ }^{2}$, C. R. Roswell ${ }^{1}$, C. J. Foley ${ }^{1,3}$ and T. O. Höök ${ }^{1,3}$ \\ ${ }^{1}$ Department of Forestry and Natural Resources, Purdue University, West Lafayette, IN, USA; ${ }^{2}$ National Oceanic and \\ Atmospheric Administration, Great Lakes Environmental Research Laboratory, Muskegon, MI, USA; ${ }^{3}$ Illinois-Indiana Sea \\ Grant, Purdue University, West Lafayette, IN, USA
}

\begin{abstract}
Summary
Trout-perch are abundant in many North American aquatic systems, but the ecological roles of trout-perch as predators, competitors and prey remain relatively understudied. To elucidate the ecological role of trout-perch in Saginaw Bay (Lake Huron, North America), the spatial and temporal diet composition was quantified and the frequency of occurrence of troutperch in diets of piscivorous walleye and yellow perch was evaluated. From May through November 2009-2010, troutperch and their potential predators and prey were collected monthly from five sites in Saginaw Bay using bottom-trawls. Trout-perch were abundant components of the Saginaw Bay fish community, and in 2009 , represented $13.5 \%$ of fish collected in trawls, with only yellow perch $(38 \%)$ and rainbow smelt $(19.1 \%)$ being more common. Trout-perch primarily consumed Chironomidae ( $84.0 \%$ of diet biomass) and exhibited strong, positive selection for Chironomidae and Amphipoda, suggesting that their diet preferences overlap with the economically important yellow perch and juvenile walleye. Energy content of trout-perch averaged $4795 \mathrm{~J} \mathrm{~g}^{-1}$ wet and was similar to yellow perch (4662 $\mathrm{J} \mathrm{g}^{-1}$ wet) and round goby (3740 $\mathrm{J} \mathrm{g}^{-1}$ wet). Thus, they may provide a comparable food source for larger piscivorous fish. However, despite their high energy density, abundance, and spatial overlap with other fish prey species, trout-perch were very rare in diets of piscivorous walleye and yellow perch in Saginaw Bay, indicating that trout-perch are a weak conduit of energy transfer to higher trophic levels.
\end{abstract}

\section{Introduction}

Benthic fishes are important components of aquatic ecosystems, directly and indirectly impacting macroinvertebrate abundance, water quality, and the abundance of other fishes through competitive, behavioral, and predatory interactions (Gilinsky, 1984; Meijer et al., 1990; Havens, 1993). More than half of all prey consumed in North American temperate lakes can originate from benthic energy pathways, either via direct consumption of benthic invertebrates or indirectly through consumption of benthic fishes (Vander Zanden and Vadeboncoeur, 2002). Trout-perch Percopsis omiscomaycus are small-bodied, benthivorous fishes found in deep lakes or large streams from Alaska to eastern Canada (Baker and Wallus, 1990). Despite their broad geographic range, locally

\footnotetext{
* Present address: CILER, University of Michigan, Ann Arbor, MI,
} USA. high abundances, and taxonomic distinctness, trout-perch are relatively understudied, and their role in food webs of the Laurentian Great Lakes is not well-understood.

Past studies demonstrate that trout-perch feed primarily on benthic invertebrates (Ogle et al., 1995; Nelson and Dick, 2002), although they also consume fish eggs and, occasionally, small fish (Nelson and Dick, 2002). Therefore, under resource limitations trout-perch may compete with other benthically feeding fishes. For example, in Lake Superior trout-perch may share feeding patterns with ruffe Gymnocephalus cernua, as both consume Chironomidae larvae, Cladocera, and Copepoda and move inshore at night to feed (Ogle et al., 1995). Moreover, in various systems trout-perch distributions are known to overlap in space and time with ecologically and economically important benthivorous fishes, such as yellow perch Perca flavescens, juvenile walleye Sander vitreus, and round goby Neogobius melanostomus (e.g. Fielder and Thomas, 2006).

In natural settings, various fishes will consume trout-perch, e.g. northern pike Esox lucius (Lawler, 1954; Magnuson and Smith, 1963), burbot Lota lota (Magnuson and Smith, 1963), yellow perch (Sibley, 1929; Magnuson and Smith, 1963), walleye, (Sibley, 1929; Lawler, 1954; Magnuson and Smith, 1963), and freshwater drum Aplodinotus grunniens (Magnuson and Smith, 1963). However, trout-perch are rarely preferred prey. In fact, in Lake Erie walleye and yellow perch positively select various similar-sized soft-rayed fishes as prey, but negatively select trout-perch (Knight et al., 1984). Moreover, while walleye will consume trout-perch in a laboratory setting (Hall and Rudstam, 1999), trout-perch are only rarely observed in diets of wild walleye (Lawler, 1954; Parsons, 1971; Craig and Babaluk, 1989; Fielder and Thomas, 2006) or yellow perch (Magnuson and Smith, 1963). Interestingly, a tethering trial indicated that trout-perch should be roughly as vulnerable to predation as other prey fish, e.g. yellow perch (Laplante-Albert et al., 2010). Thus, it is unclear why piscivores seemingly avoid trout-perch as prey, although possibilities include relatively low energy content, undescribed avoidance behavior, or some unknown costs for digesting trout-perch.

Saginaw Bay, a shallow, eutrophic embayment of Lake Huron, is a highly altered ecosystem, having experienced high contaminant and nutrient loadings (Cha et al., 2010), multiple species invasions (Fielder and Thomas, 2006), and many other anthropogenic influences during the past century. Population numbers of key fish (e.g., walleye and yellow perch) (Ivan et al., 2011) and invertebrate (e.g. burrowing mayflies, dreissenid mussels) species have fluctuated drastically in response to these stressors (Fielder et al., 2000; Fielder and Thomas, 2006). 
Trout-perch densities, however, have remained relatively steady, and this species at present is roughly as abundant in Saginaw Bay as it was during the period 1970-2006 (Fielder et al., 2000; Fielder and Thomas, 2006).

Our objective was to describe the trophic interactions of trout-perch in Saginaw Bay, Lake Huron by evaluating their role as both predator and prey. We quantified diet composition of individual trout-perch and assessed their selectivity for the most abundant benthic prey types. Due to heterogeneity in temperature and substrates in Saginaw Bay, we assessed spatial and temporal variation in diet composition and prey selectivity of trout-perch. In addition, we evaluated the suitability of trout-perch as prey by quantifying their energy content and utilization as prey by piscivorous walleye and yellow perch. Based on findings from past studies, we hypothesized that trout-perch would consume similar prey as other benthivorous fishes in Saginaw Bay, but that economically important piscivorous fish would not target trout-perch as an important diet component.

\section{Methods}

\section{Field collection}

We sampled fish from five sites, once per month from May through November in 2009 and 2010 (except October 2010; Fig. 1). At each site, we towed a trawl (7.6 m semi-balloon bottom trawl with a $13 \mathrm{~mm}$ stretched-mesh cod-liner) at $2.5 \mathrm{kt}$ for $10 \mathrm{~min}(\mathrm{n}=3-7$ trawl tows per sampling occasion). Sites differed in physical habitat characteristics: depth and substrate (Table 1). Immediately following collection, we sorted, identified and froze fish in water. We sampled benthic macroinvertebrates using duplicate ponar grabs $\left(0.052 \mathrm{~m}^{2}\right)$ and subsequently sieved contents through $500 \mu \mathrm{m}$ mesh and stored samples in 5\% formaldehyde with Rose Bengal stain.

\section{Laboratory analysis}

We identified and enumerated benthic macroinvertebrates from ponar samples under a dissecting microscope. We

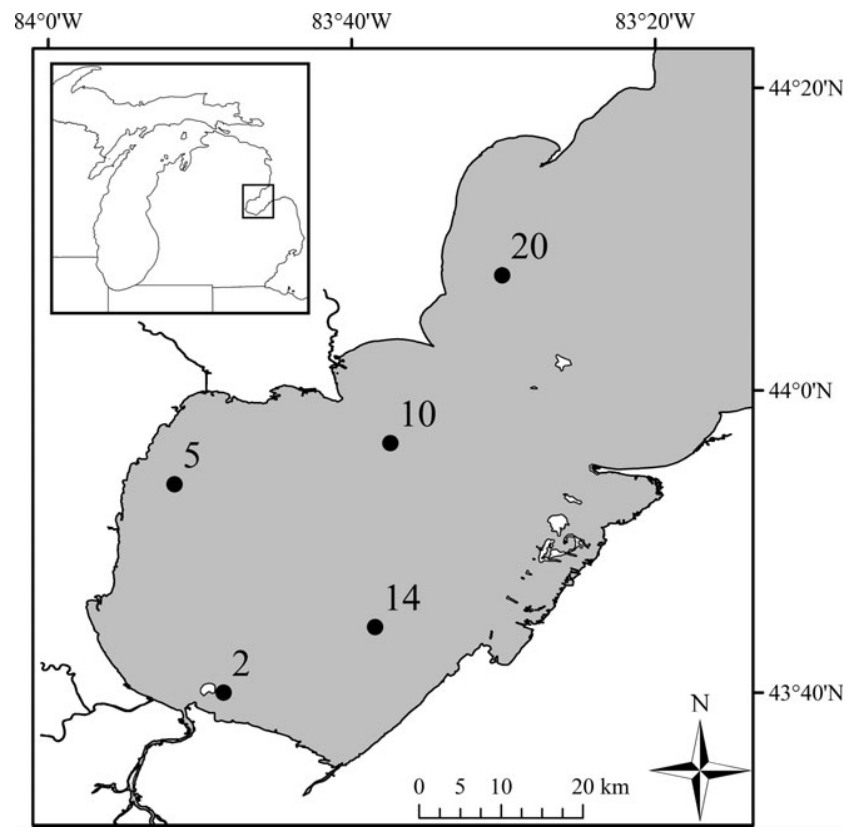

Fig. 1. Sampling sites in Saginaw Bay, Lake Huron enumerated the number of individual trout-perch per trawl and measured total length $( \pm 0.1 \mathrm{~mm})$ and mass $( \pm 0.01 \mathrm{~g})$ of up to 30 randomly selected individuals per trawl.

To describe trout-perch diet patterns, we analyzed stomach contents of up to 20 individuals per site per month. After removing stomach contents, we dried whole fish at $70^{\circ} \mathrm{C}$ for $48 \mathrm{~h}$. We examined stomach contents under a dissecting microscope, counting all possible whole organisms or head capsules for benthic macroinvertebrates and all possible whole organisms or eyespots for zooplankton. We identified diet items to various taxonomic levels, typically order or family for benthic macroinvertebrates and genus for zooplankton. To estimate biomass of different invertebrates in sediment samples and trout-perch diets, we photographed up to 20 individuals of each prey type using a dissecting microscope and 318CU Micrometrics camera, measured prey items $( \pm 0.01 \mathrm{~mm})$ with Image $\mathbf{J}$ software (Rasband 2009), and calculated dry biomass using published length-weight regressions (Dumont et al., 1975; Nalepa and Quigley, 1980; Smock, 1980; Culver et al., 1985; Makarewicz and Jones, 1990; Haugen and Rygg, 1996; Benke et al., 1999; Lemke and Benke, 2004; Soetaert et al., 2009; Riseng C. and Eaton L., University of Michigan, unpublished data). Whenever possible, we measured whole prey items; however, for some partially digested items we had to resort to measuring head capsule width or length. For taxon constituting $>20$ individual diet items, we applied the mean taxon-specifc, dry-mass estimate to determine masses of remaining diet items. For each taxon, we summed dry-mass and used these estimates to determine the proportional contribution by mass of each prey type to the whole stomach contents or benthic sample. After photographing, we dried whole stomach contents at $70^{\circ} \mathrm{C}$ for $48 \mathrm{~h}$, and measured total diet dry mass $(0.1 \mathrm{mg})$.

We assessed the frequency of occurrence of trout-perch as prey by examining stomach contents of the main piscivores found in Saginaw Bay: juvenile and adult walleye and adult yellow perch. We collected fish via the same trawls described above, removed stomachs and identified stomach contents to the lowest level possible.

Finally, to evaluate the suitability of trout-perch as prey, we determined energy densities of individual trout-perch collected at site 10 during May, July September and November of 2009 and $2010(\mathrm{n}=98 ; 10-20$ fish per month). We used stratified random sampling to select fish for energy density measurement using $0-60,61-95,95+\mathrm{mm}$ size classes, as these were age groups observed in Magnuson and Smith (1963). We homogenized dried $\left(70^{\circ} \mathrm{C}\right.$ for $\left.72 \mathrm{~h}\right)$ trout-perch after removal of gut contents and determined energy density using a Parr 1261 Bomb Calorimeter.

\section{Data analysis}

To assess temporal variability, we examined how trout-perch diet composition (prey taxa-specific percent of total identifiable dry diet mass) and selectivity changed at a single site (site 10) across 5 months (May, July, August, September, November; both years). While our temporal analysis was limited to one site, site 10, which differed somewhat from other sites in trout-perch diet, selectivity, and habitat, this site represented 56.4 and $82.3 \%$ of trout-perch caught in trawls during 2009 and 2010, respectively. Therefore, this site was useful for indexing diet patterns and exploring temporal effects on trout-perch prey consumption. We examined the effect of geographic location on diet composition and 
Table 1

Site characteristics, Saginaw Bay, Lake Huron, including depth, substrate, number of benthic invertebrate samples, benthic invertebrate biomass with and without dreissenid mussels, Chironomidae biomass and Amphipoda biomass. All biomass units in $\mathrm{mg} \mathrm{m}^{-2} \mathrm{dry}$, with SE in parentheses

\begin{tabular}{|c|c|c|c|c|c|c|c|}
\hline Site & $\begin{array}{l}\text { Depth } \\
\text { (m) }\end{array}$ & Substrate & $\begin{array}{l}\text { Sample } \\
\text { size } \\
\text { (no. of } \\
\text { ponar } \\
\text { grabs) }\end{array}$ & $\begin{array}{l}\text { Total } \\
\text { invertebrate } \\
\text { biomass }\end{array}$ & $\begin{array}{l}\text { Invertebrate } \\
\text { biomass } \\
\text { (excluding } \\
\text { dreissenids) }\end{array}$ & Chironomidae & Amphipoda \\
\hline SB2 & 3.9 & Rock \& cobble & 26 & $43347\left(\begin{array}{lll}11 & 095\end{array}\right)$ & $170(39)$ & $30(6)$ & $60(23)$ \\
\hline SB5 & 3.6 & $\begin{array}{l}\text { Cobble, gravel \& } \\
\text { sand }\end{array}$ & 22 & $25700(9651)$ & 850 (237) & $160(74)$ & $390(109)$ \\
\hline SB10 & 12.2 & Silt \& muck & 30 & $920(148)$ & 910 (149) & $640(138)$ & $20(6)$ \\
\hline SB14 & 3.8 & Sand & 22 & $22050(4671)$ & $390(191)$ & $20(6)$ & $260(181)$ \\
\hline SB20 & 17.7 & Sand \& silt & 20 & $280(67)$ & $220(70)$ & $110(61)$ & $5(2)$ \\
\hline
\end{tabular}

selectivity by comparing diets of fish collected from all five sites during 2 months when we collected relatively large numbers of trout-perch across all sites: July 2009 and August 2010. To minimize potential biases related to prey consumption of different sizes of trout-perch, we limited monthly and site comparisons of diet contents and selectivities to individuals between $40-110 \mathrm{~mm}$.

For each fish analyzed for stomach contents, we calculated Chesson's alpha (Chesson, 1983) for seven common benthic prey categories found in both ponar samples and trout-perch diets: Amphipoda, Chironomidae (pupae and larvae), Ephemeroptera, Isopoda, Nematoda, Platyhelminthes, and Trichoptera). Though Chydoridae and Oligochaeta were relatively abundant in trout-perch diets and Dreissena mussels (D. bugensis and D. polymorpha) were abundant in the environment, we did not include these three taxa in selectivity calculations. Chydoridae are not effectively sampled using ponar samples or zooplankton tows; Oligochaeta collected in ponars and found in stomachs were frequently fragmented, rendering enumeration impossible; and the high abundance of dreissenid mussels in the environment coupled with their complete absence in trout-perch diets would have led to uninformative selectivity values for all other taxa. We assumed that Chironomidae pupae in trout-perch diets had recently emerged as trout-perch tend to fed benthically. Positive selection for prey occurred with a Chesson's alpha value above $0.143\left(\mathrm{~m}^{-1}\right.$, where $\mathrm{m}=$ the number of taxa; Fulford et al., 2006). Finally, to evaluate trout-perch size effects on prey consumption, we regressed mean lengths of key prey items (Chironomidae and Amphipoda) and total trout-perch length.

To explore the potential utility of trout-perch as prey, we compared trout-perch energy densities among months (May, July, September, and November) and between years (2009 and 2010) at site 10. An ANCOVA [between-subjects factors: month (May, July, September, November), year (2009, 2010); covariate: length] revealed a significant interaction between month and length, $\mathrm{F}_{3,82}=4.684, \mathrm{P}=0.005, \eta_{\mathrm{p}}{ }^{2}=0.146$, and year and length, $\mathrm{F}_{1,82}=19.605, \mathrm{P}<0.001, \eta_{\mathrm{p}}{ }^{2}=0.193$; therefore, a one-way ANOVA was conducted (with years pooled) with Tamhane comparison. We defined $\alpha=0.05$ and used SPSS version 18.0 (SPSS, 2010) for all data analyses.

\section{Results}

Trout-perch comprised a large proportion of the fish caught in bottom trawls in 2009 and 2010. For example, in 2009, trout-perch represented $13.5 \%$ of all species (by number) caught in trawls, third behind yellow perch $(38.0 \%)$ and rainbow smelt (19.1\%). In 2009 and 2010, we collected a total of 4775 trout-perch and analyzed diets of 227 and 176 trout-perch, respectively.

During both years, trout-perch length-frequency distributions were initially unimodal and then developed into bimodal distributions in August and September (Fig. 2), indicating the presence of multiple annual cohorts during these months. Young-of-year trout-perch emergence appeared to be high in July and August of both years, although small $(<50-\mathrm{mm})$ individuals were caught in almost all months. In 2009, the length-frequency distributions suggested a more protracted spawning season as compared to 2010 (Fig. 2).

Trout-perch diets were dominated by Chironomidae larvae, which occurred in $89.6 \%$ and $93.9 \%$ of non-empty trout-perch stomachs in 2009 and 2010, respectively, and represented a large proportion of the biomass for all size classes (Fig. 3). In contrast, dreissenids, the most abundant benthic invertebrates in Saginaw Bay (Table 1) (Nalepa et al., 1995, 2003), were entirely absent from trout-perch diets.

Diet composition of trout-perch varied spatially (among sites), temporally (across years and months), and with size (Fig. 3). While the proportional composition (biomass) of prey categories varied fairly weakly with size, a) biomass of Amphipoda tended to be relatively high in very large trout-perch $(>110 \mathrm{~mm})$ and b) zooplankton were an important diet biomass component for only very small trout-perch $(<30 \mathrm{~mm})$. Thus, to facilitate comparison of diet composition and selectivity across sites and months, we limited these comparisons to trout-perch between $40-110 \mathrm{~mm}$ (Figs $3 \mathrm{c}-\mathrm{f}$ ). Within this size range, biomass of Chironomidae larvae still dominated diets of troutperch across most months at site 10 (Fig. 3c,d) and across most sites in July 2009 and August 2010 (Fig. 3e,f). However, other diet taxa were seasonally, locally or numerically important: (i) In July-September 2009, trout-perch diets also included a large proportion of Amphipoda; (ii) While Chironomidae pupae were large contributors to trout-perch diets in May 2010, this prey category did not appear in trout-perch diets until July in 2009; (iii) On some sampling occasions, other benthic invertebrates (e.g. Oligochaeta) were an important component of trout-perch diets; (iv) Finally, Chydoridae were a numerically important component of trout-perch diets (constituting 10.1\% of diet items identified), but due to their small individual size Chydoridae represented a minor diet category based on biomass. 

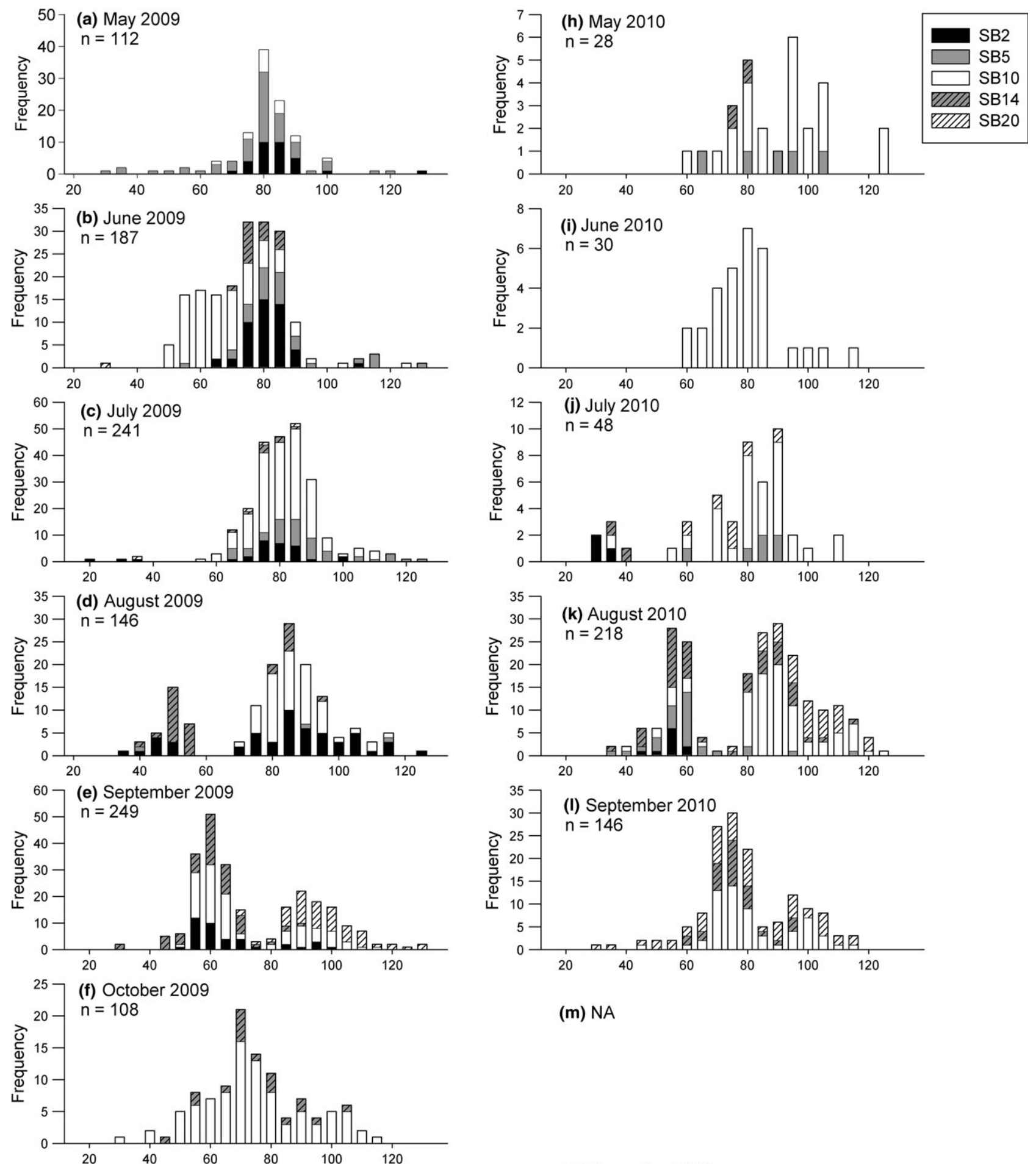

(m) NA
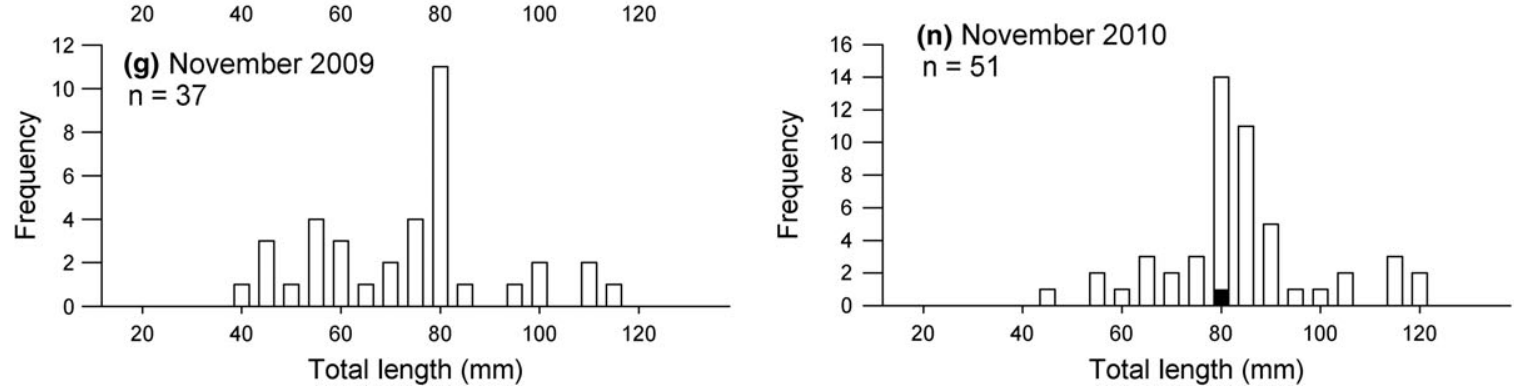

Fig. 2. Total length (mm) frequency distribution of trout-perch collected in 2009 (a) May, (b) June, (c) July, (d) August, (e) September, (f) October, and (g) November and in 2010 (h) May, (i) June, (j) July, (k) August, (l) September, (m) October not sampled, and (n) November for all sites in Saginaw Bay, Lake Huron. Note that $y$-axis scales vary among months. Dates of collection for fish with completed diets by month/day: $2009-5 / 5,5 / 6,6 / 2,7 / 7,7 / 8,7 / 23,8 / 4,9 / 1,9 / 2,10 / 5,11 / 3 ; 2010-5 / 10,6 / 7,7 / 7,8 / 9,8 / 10,8 / 11,9 / 23,11 / 10$ 
(a) 2009 Size

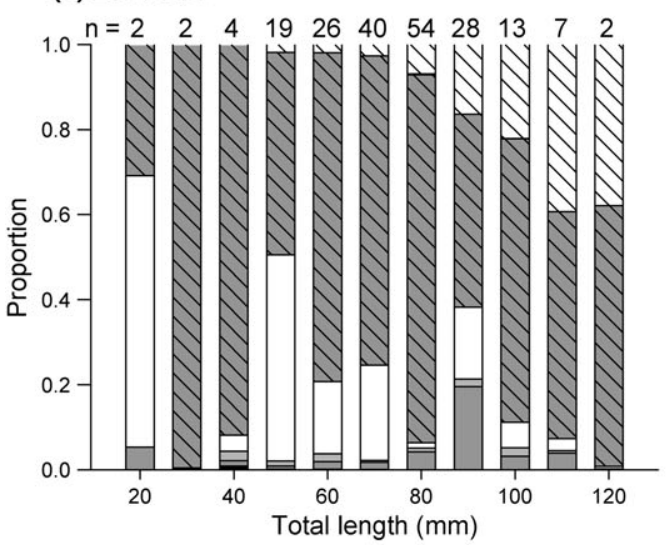

(c) 2009 Temporal

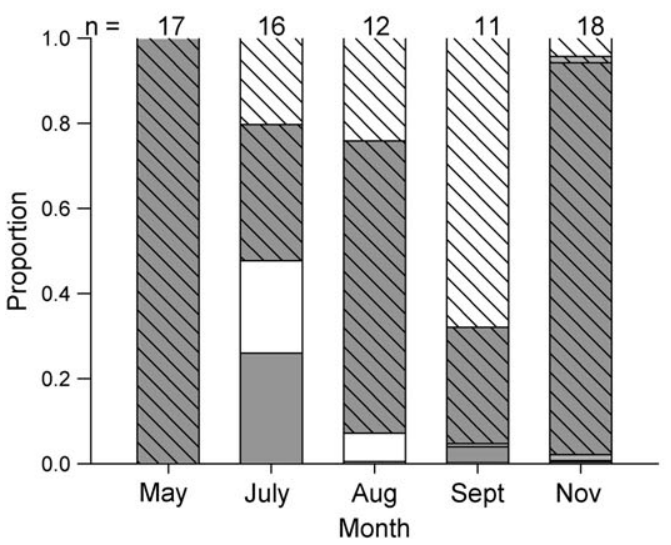

(e) 2009 Spatial

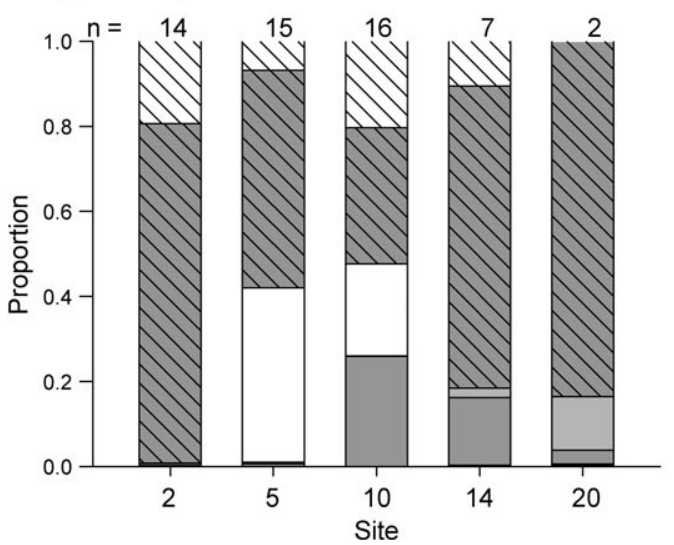

(b) 2010 Size

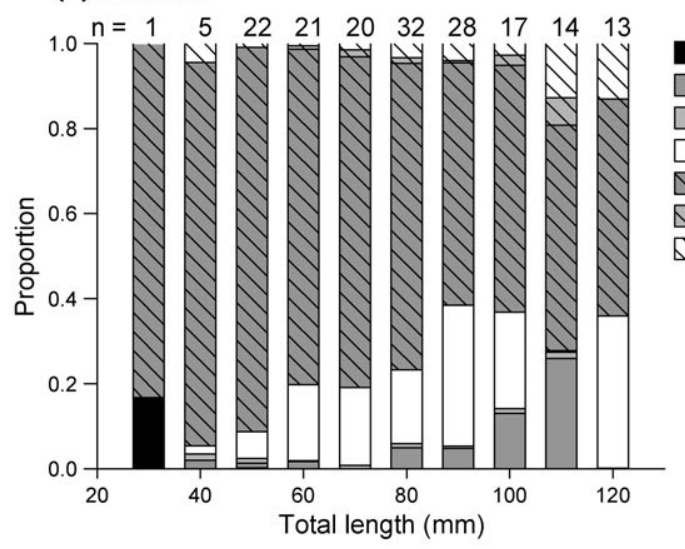

(d) 2010 Temporal

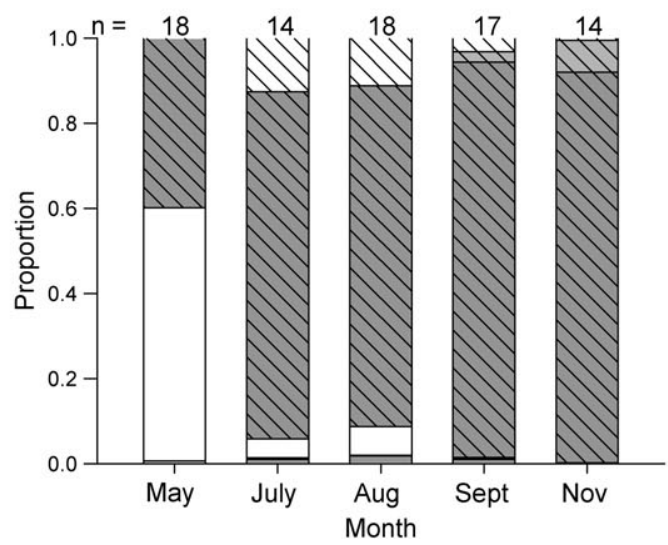

(f) 2010 Spatial

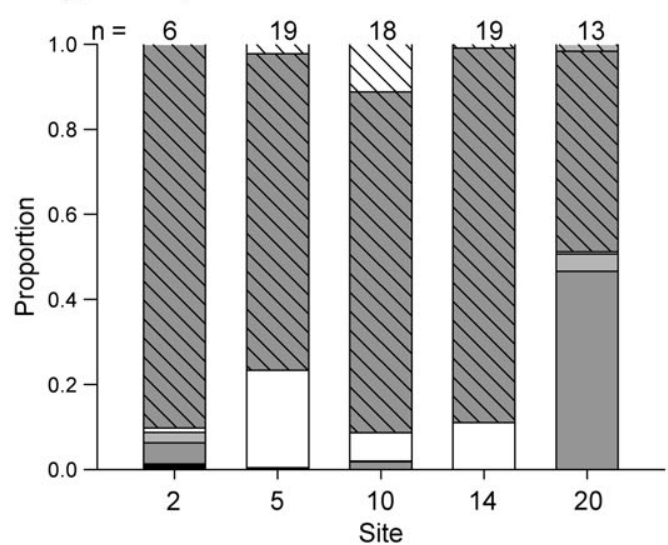

Fig. 3. Trout-perch diet proportions by mass in 2009 (a,c,e) and 2010 (b,d,f). Diet content compared across total lengths (a, b) and diets of trout-perch between $40-110 \mathrm{~mm}$ compared among months (c, d), and sites (e, f)

To determine if differences in prey consumption were driven by prey availability or active prey selection, we indexed troutperch selectivity for seven benthic prey items. Trout-perch strongly, positively selected for Chironomidae during most months and at most sites (Fig. 4). During July 2009 and August 2010, Chironomidae were positively selected by troutperch at all sites. However, at site 10, trout-perch targeted Amphipoda more strongly than Chironomidae (Fig. 4a,b). In addition, in 2009, trout-perch positively selected Nematoda at site 5 and Ephemeroptera at site 14 (Fig. 4a).

Prey selectivity patterns at a single site (10) varied over time. In 2009, trout-perch positively selected Chironomidae in all months. However, in July and August 2009, Amphipoda were more strongly selected than Chironomidae, and in September 2009, Nematoda were also positively selected (Fig. 4c). In contrast, in 2010 the most highly selected prey item switched from Chironomidae (May-July) to Amphipoda (August-September) and Isopoda (November) (Fig. 4d), such that, Chironomidae were negatively selected in November 2010. It was not possible to estimate selectivity (Chesson's alpha) for Amphipoda in September or November 2009 as these invertebrates were not collected in the ponars. However, their presence in trout-perch diets suggests that they were strongly positively selected during these months. 

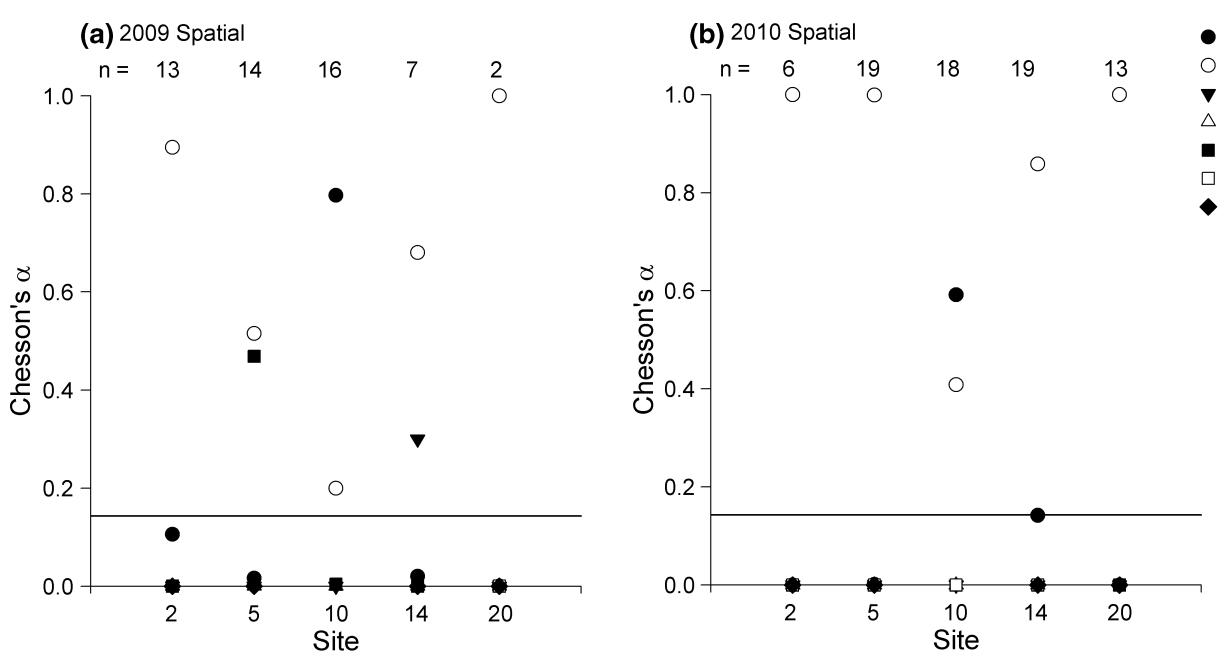

(c) 2009 Temporal

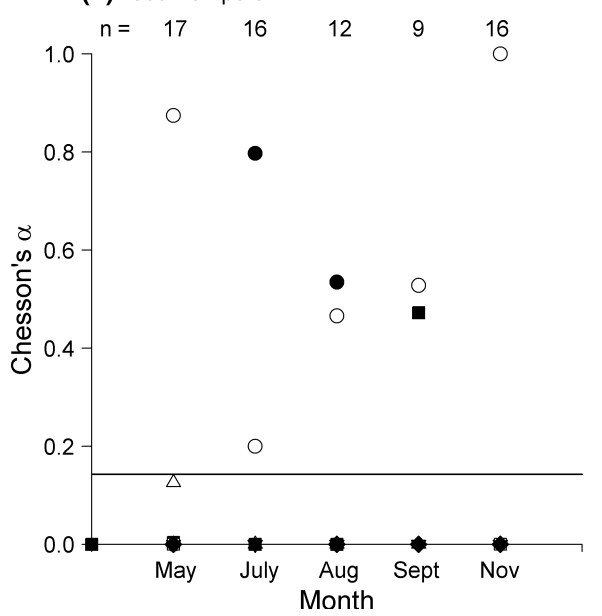

(d) 2010 Temporal

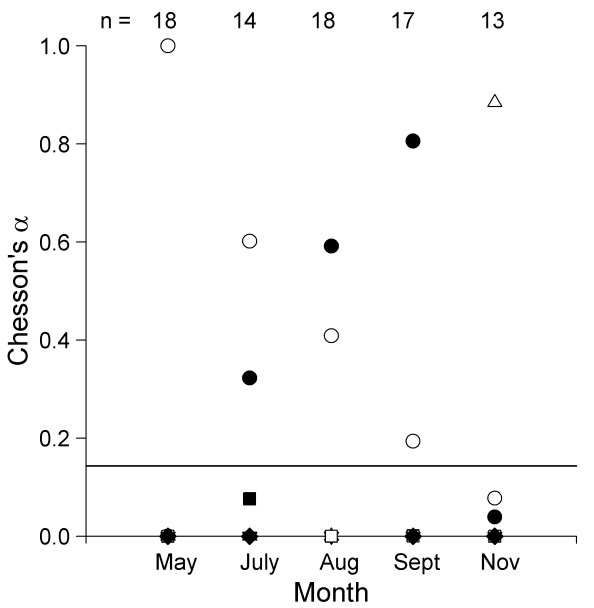

Fig. 4. Mean Chesson's alpha calculated for benthic prey items based on diets of trout-perch (40-110 mm TL) and estimated macroinvertebrate abundance from ponar samples for (a) all sites July 2009, (b) all sites August 2010, (c) site 10 in May, July, August, September, November 2009 and (d) site 10 in May, July, September, August, November 2010. Numbers (n) of individual trout-perch diets examined presented for each site and month

Sizes of Chironomidae and Amphipoda consumed by trout-perch varied with trout-perch length. While significant, the positive association between Chironomidae and troutperch lengths was relatively weak $\left(2009, R^{2}=0.05, \mathrm{n}=154\right.$, $\mathrm{P}=0.007 ; 2010, R^{2}=0.05, \mathrm{n}=128, \mathrm{P}=0.010$; Fig. 5a,b). In contrast, the positive association between Amphipoda size and trout-perch length was stronger $\left(2009, R^{2}=0.20\right.$, $\mathrm{n}=52, \quad \mathrm{P}<0.001 ; \quad 2010, \quad R^{2}=0.34, \quad \mathrm{n}=40, \quad \mathrm{P}<0.001 ;$ Fig. 5c,d).

Trout-perch exhibited seasonal variation in energy density, although only two months differed statistically (September $4943 \mathrm{~J} \mathrm{~g}^{-1}$ vs July $4571 \mathrm{~J} \mathrm{~g}^{-1} ; \mathrm{P}=0.003$ ) (Fig. 6). The mean energy density of trout-perch $40-110 \mathrm{~mm}$ was $4795 \mathrm{~J} \mathrm{~g}^{-1}$ wet, which is greater than the energy densities of similar sized round goby (3740 $\mathrm{J} \mathrm{g}^{-1}$ wet) (C. Foley unpublished data) and yellow perch (4662 $\mathrm{J} \mathrm{g}^{-1}$ wet) (Roswell, 2011) in Saginaw Bay.

Trout-perch were uncommon in diets of walleye and yellow perch. We examined diets of 1590 piscivorous age- 0 walleye, 335 age- 1 + walleye and 168 potentially piscivorous yellow perch (79-321 mm total length) and only 5 troutperch were found out of a total of 1370 piscine diet items (i.e. trout-perch constituted $0.4 \%$ of piscine diet items).

\section{Discussion}

Trout-perch appear to be a numerically important component of the Saginaw Bay fish community, composing approximately $13 \%$ (by number) of the total catch in trawls. However, economically and ecologically important piscivores (e.g., walleye and yellow perch) do not consume trout-perch consistently, suggesting that trout-perch biomass is not transferred effectively to higher trophic levels. Moreover, trout-perch appear to consume similar benthic prey (e.g. Chironomidae and Amphipoda) preferentially. While competition among species has not been explicitly evaluated, high diet overlap points to the plausibility of trout-perch negatively impacting other fishes through resource competition.

Trout-perch potentially compete with native species in Saginaw Bay. Age-0 walleye consume Chironomidae and zooplankton (Beck et al., 1998; S. Pothoven, unpublished data) prior to their switch to piscivory. Similarly, young yellow perch tend to consume a combination of zooplankton and benthic invertebrates (Fielder and Thomas, 2006), and in Saginaw Bay positively select Chironomidae as prey (Roswell, 2011). Due to seemingly high diet overlap, it is possible that trout-perch are competing with these species for prey resources; however, this hypothesis is untested in Saginaw Bay. 

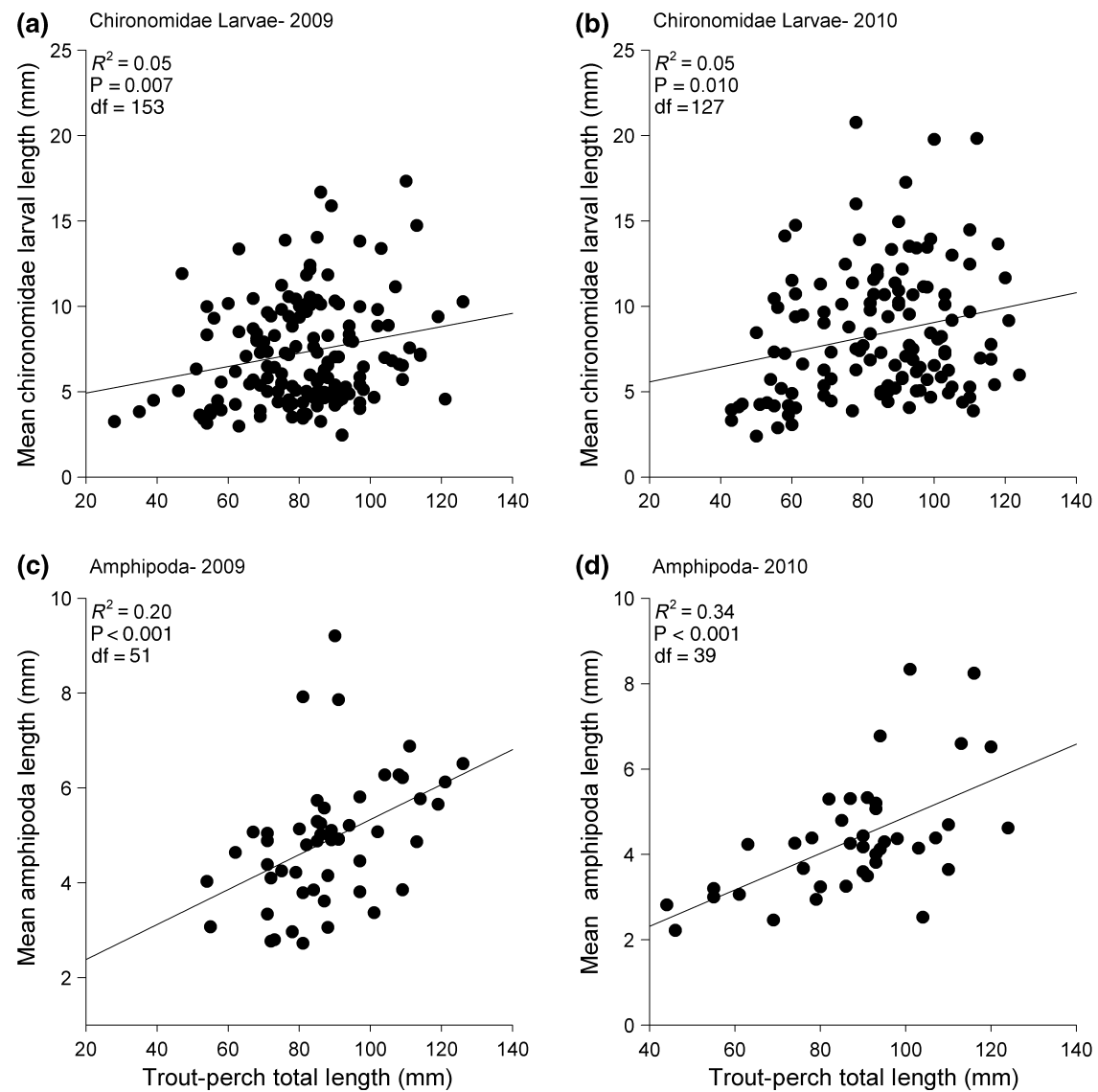

Fig. 5. Total lengths $(\mathrm{mm})$ of individual trout-perch vs mean length $(\mathrm{mm})$ of consumed Chironomidae larvae and Amphipoda in 2009 (a,c) and $2010(\mathrm{~b}, \mathrm{~d})$

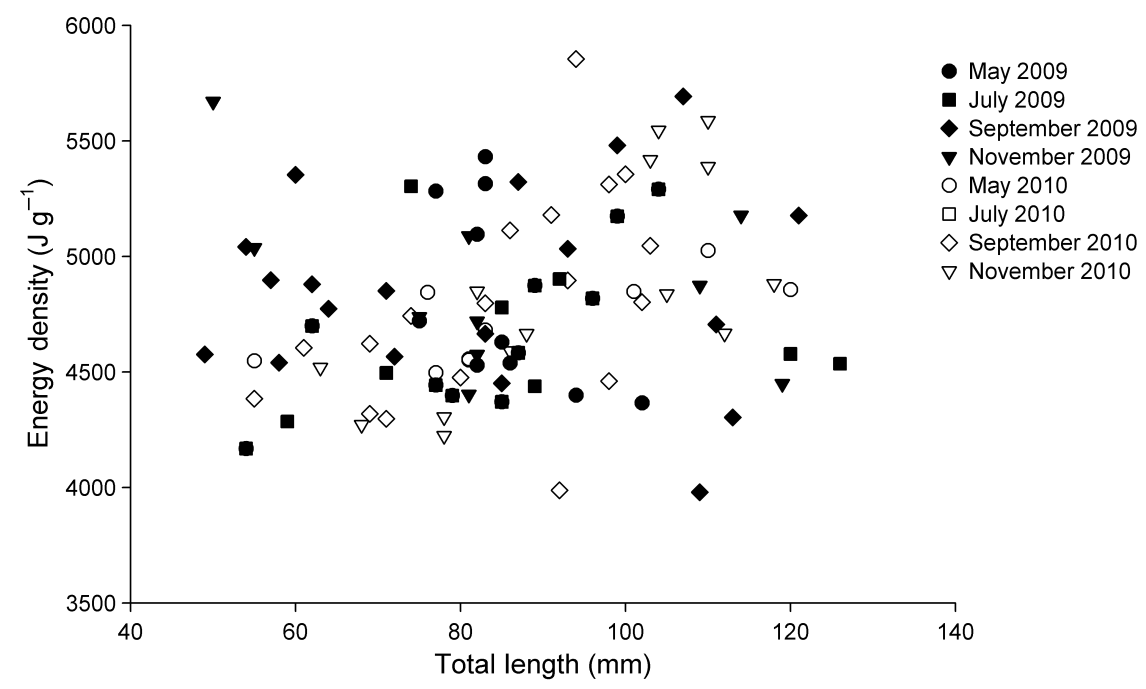

Fig. 6. Energy density $\left(\mathrm{J} \mathrm{g}^{-1}\right.$ wet mass) vs mean total length $(\mathrm{mm})$ of individual trout-perch collected in Saginaw Bay during May, July, September, November 2009 and 2010

The invasive round goby is another potential trout-perch competitor in Saginaw Bay. In other regions of the Great Lakes, round gobies have displaced various native benthivorous fishes, including logperch Percina caprodes (Corkum et al., 2004) and mottled sculpin Cottus bairdii (Janssen and Jude, 2001), and in Saginaw Bay johnny darters Etheostoma nigrum have declined since the round goby invasion (Fielder and Thomas, 2006). Such competitive displacement by round gobies appears to have occurred through both resource competition and aggressive round goby behavior leading to interference competition (Janssen and Jude, 2001). However, available data suggest round gobies are not displacing trout- perch in Saginaw Bay (present study; Fielder and Thomas, 2006). Apparent coexistence of gobies and trout-perch may be driven by several factors. First, trawling was over relatively soft substrates while gobies may prefer hard substrates. Thus, differential substrate preferences may partially explain the coexistence of trout-perch and round gobies. On the other hand, we collected both trout-perch and round goby at all sampled sites, suggesting that at least some spatial overlap does occur. Second, spatial disparity in overlap of similar sized gobies and trout-perch may also reduce competition, as small gobies are most likely to consume similar sized prey organisms as trout-perch (C. Foley, unpublished data) 
Finally, susceptibility to predation may also mediate the coexistence of trout-perch and round goby.

Adult walleye in Saginaw Bay consume large numbers of young yellow perch and round goby (Fielder and Thomas, 2006; S. Pothoven, unpublished data), but seemingly avoid trout-perch (present study). Although this is consistent with other systems where walleye negatively select for trout-perch (Parsons, 1971; Knight et al., 1984), the mechanisms underlying such negative selection remain unclear. We demonstrated that energy densities for trout-perch are similar or higher than other forage fishes in Saginaw Bay, and hence, lack of energetic return is not a plausible explanation for negative selection. Walleye and other predators may consume trout-perch when other prey resources are scarce, as is the case in western Lake Erie, where walleye eat trout-perch in years when other prey are scarce (Hartman and Margraf, 1992).

Prey consumption patterns of trout-perch in Saginaw Bay were similar to diets of trout-perch in other systems. Chironomidae and Amphipoda, seemingly the most important diet items for trout-perch in Saginaw Bay, were also important numeric diet items consumed by trout-perch in other systems (Crowder et al., 1981; Spafford, 1999; Nelson and Dick, 2002). Additional prey types were also similar across systems (Spafford, 1999; Nelson and Dick, 2002). However, troutperch in Saginaw Bay consumed a relatively large number of Chydoridae as compared to Lake Michigan (10.1\% of diet items in Saginaw Bay vs $<1 \%$ in Lake Michigan; Crowder et al., 1981). Chydoridae appear to be an important component of trout-perch diets, but their small size and demersal behavior renders this benthic crustacean difficult to sample with either traditional benthic sampling gear (e.g. ponar) or plankton nets, making selectivity difficult to measure. Chydoridae may be important prey for trout-perch and other fish species in Saginaw Bay (e.g. yellow perch; Roswell, 2011). However, Chydoridae remain relatively understudied and future consideration should be given to this potentially important component of some aquatic food webs. Finally, unlike other studies (Crowder et al., 1981; Nelson and Dick, 2002; Swanson et al., 2003; Roseman et al., 2006) trout-perch in Saginaw Bay did not consume fish eggs and larvae, and troutperch did not consume dreissenid mussels, the most abundant benthic invertebrate in Saginaw Bay.

Diet patterns of trout-perch in Saginaw Bay varied temporally, spatially, and by individual size. Temporal diet differences likely partially reflect invertebrate emergence phenologies. For example, Chironomidae pupae were an important diet component at site 10 in May 2010 (59.5\% of total diet biomass), but this prey type was less important during other time periods, including May 2009. Chironomidae pupae are likely utilized by trout-perch during Chironomidae emergence, which can vary across years (e.g. higher spring temperatures in 2010 likely contributed to earlier emergence). Spatial diet differences likely reflect differences in prey availability. At site 10, trout-perch consumed more Amphipoda, while troutperch at site 20 consumed more Chydoridae and Oligochaeta. We speculate that trout-perch utilize Oligochaeta and Chydoridae as alternative food sources when other prey are lacking. In fact, while diet patterns varied among sites, prey selectivities were fairly consistent. Chironomidae were the most strongly selected prey at all sites, except site 10, where large Amphipoda and Isopoda were also strongly positively selected. As far as is known, the effect of trout-perch size on prey selection has not been fully evaluated (but see Baker and Wallus, 1990). Com- pared to many other fishes (Mittelbach and Persson, 1998; Montaña et al., 2011; Specziár, 2011), the influence of individual size on prey consumed by trout-perch in Saginaw Bay was relatively weak. Nonetheless, larger trout-perch in Saginaw Bay were more likely to consume larger prey, for example consuming a greater proportion of Amphipoda. In addition, we document positive associations between trout-perch size and the mean size of Chironomidae and Amphipoda consumed. Finally, zooplankton appeared to be an important diet component for very small trout-perch, but not for larger individuals. Collectively, temporal, spatial and size-based variation in prey availability, selection and diet composition demonstrate the plasticity of trout-perch diets and potential biases of attempting to describe the ecological role of trout-perch using single sampling occasions and locations. Trout-perch are abundant in many systems throughout North America, including the Laurentian Great Lakes and in Saginaw Bay. Their preference and consumption of important benthic species make them a potential competitor with other more economically important species. Moreover, trout-perch are not actively consumed by many piscivores and may act as a trophic bottleneck in some of these systems. Future studies could evaluate why troutperch are not more actively targeted by piscivores and explore if certain habitat conditions would increase susceptibility of trout-perch as prey.

\section{Acknowledgements}

This project was funded by the National Oceanic and Atmospheric Administration's Center for Sponsored Coastal and Ocean Research and Purdue University's Discovery Park Undergraduate Research Program and Summer Undergraduate Research Fellowships. We thank the crew of NOAA-GLERL's research vessels. This is NOAA-GLERL contribution number 1634 .

\section{References}

Baker, J. M.; Wallus, R., 1990: Family Percopsidae: trout-perches. In: Reproductive biology and early life history of fishes in the Ohio River drainage, Vol. 5: Aphredoderidae through Cottidae, Moronidae, and Sciaenidae. R. Wallus, T. P. Simon (Eds). Tennessee Valley Authority, Chattanooga, TN, pp. 21-32.

Beck, H. D.; Starostka, A. B.; Willis, D. W., 1998: Diet overlap of age- 0 walleye and white bass in Lake Poinsett, South Dakota. J. Freshw. Ecol. 13, 425-431.

Benke, A. C.; Huryn, A. D.; Smock, L. A.; Wallace, J. B., 1999: Length-mass relationships for freshwater macroinvertebrates in North America with particular reference to the southeastern United States. J. N. Am. Benthol. Soc. 18, 308-343.

Cha, Y.; Stowe, C. A.; Reckhow, K. W.; DeMarchi, C.; Johengen, T. H., 2010: Phosphorus load estimation in the Saginaw River, MI using a Bayesian hierarchical/multilevel model. Water Res. 44, 3270-3282.

Chesson, J., 1983: The estimation and analysis of preference and its relationship to foraging models. Ecology 64, 1297-1304.

Corkum, L. D.; Sapota, M. R.; Skora, K. E., 2004: The round goby, Neogobius melanostomus, a fish invader on both sides of the Atlantic Ocean. Biol. Invasions 6, 173-181.

Craig, J. F.; Babaluk, J. A., 1989: Relationship of condition of walleye (Stizostedion vitreum) and northern pike (Esox lucius) to water clarity, with special reference to Dauphin Lake, Manitoba. Can.J. Fish. Aquat. Sci. 46, 1581-1586.

Crowder, L. B.; Magnuson, J. J.; Brandt, S. B., 1981: Complementarity in the use of food and thermal habitat by Lake Michigan fishes. Can. J. Fish. Aquat. Sci. 38, 662-668.

Culver, D. A.; Boucherle, M. M.; Bean, D. J.; Fletcher, J. W., 1985: Biomass of freshwater crustacean zooplankton from lengthweight regressions. Can. J. Fish. Aquat. Sci. 42, 1380-1390. 
Dumont, H. J.; Van deVelde, I.; Dumont, S., 1975: The dry weight estimate of biomass in a selection of Cladocera, Copepoda and Rotifera from plankton, periphyton and benthos of continental waters. Oecologia 19, 75-97.

Fielder, D. G.; Thomas, M. V., 2006: Fish population dynamics of Saginaw Bay, Lake Huron 1998-2004. Fisheries Research Report 2083, Michigan Department of Natural Resources, Ann Arbor, MI.

Fielder, D. G.; Johnson, J. E.; Weber, J. R.; Thomas, M. V.; Haas, R. C., 2000: Fish population survey of Saginaw Bay, Lake Huron, 1989-97. Fisheries Research Report 2052, Michigan Department of Natural Resources, Ann Arbor, MI.

Fulford, R. S.; Rice, J. A.; Miller, T. J.; Binkowski, F. P.; Dettmers, J M.; Belonger, B., 2006: Foraging selectivity by larval yellow perch (Perca flavescens):implications for understanding recruitment in small and large lakes. Can. J. Fish. Aquat. Sci. 63, 28-42.

Gilinsky, E., 1984: The role of fish predation and spatial heterogeneity in determining benthic community structure. Ecology 65, 455-468.

Hall, S. R.; Rudstam, L. G., 1999: Habitat use and recruitment: a comparison of long-term recruitment patterns among fish species in a shallow eutrophic lake, Oneida Lake, NY, U.S.A. Hydrobiologia 408/409, 101-113.

Hartman, K. J.; Margraf, R. J., 1992: Effects of prey and predator abundances on prey consumption and growth of walleyes in western Lake Erie. Trans. Am. Fish. Soc. 121, 245-260.

Haugen, T. O.; Rygg, T. A., 1996: Food- and habitat-segregation in sympatric grayling and brown trout. J. Fish Biol. 49, 301-318.

Havens, K. E., 1993: Responses to experimental fish manipulations in a shallow, hypereutrophic lake: the relative importance of benthic nutrient recycling and trophic cascade. Hydrobiologi 254, 73-80.

Ivan, L. N.; Thomas, M. V.; Fielder, D. G.; Höök, T. O., 2011 Long-term and interannual dynamics of walleye (Sander vitreus) and yellow perch (Perch flavescens) in Saginaw Bay, Lake Huron. Trans. Am. Fish. Soc. 140, 1078-1092.

Janssen, J.; Jude, D. J., 2001: Recruitment failure of mottled sculpin Cottus bairdii in Calumet Harbor, southern Lake Michigan, induced by the newly introduced round goby, Neogobius melanostomus. J. Great Lakes Res. 27, 319-328.

Knight, R. L.; Margraf, F. J.; Carline, R. F., 1984: Piscivory by walleyes and yellow perch in western Lake Erie. Trans. Am. Fish. Soc. 113, 677-693.

Laplante-Albert, K. A.; Rodriguez, M. A.; Magnan, P., 2010: Quantifying habitat-dependent mortality risk in lacustrine fishes by means of tethering trials and survival analyses. Environ. Biol. Fish. 87, 263-273.

Lawler, G. H., 1954: Observations on the trout-perch Percopsis omiscomaycus (Walbaum), at Heming Lake, Manitoba. J. Fish. Res. Board Can. 11, 1-4

Lemke, A. M.; Benke, A. C., 2004: Growth, reproduction and production dynamics of a littoral microcrustacean, Eurycercus vernalis (Chydoridae), from a southeastern wetland, USA. J. No. Am. Benthol. Soc. 23, 806-823.

Magnuson, J. J.; Smith, L. L., 1963: Some phases of the life history of trout-perch. Ecology 44, 83-95.

Makarewicz, J. C.; Jones, H. D., 1990: Occurrence of Bythotrephes cederstroemi in Lake Ontario offshore waters. J. Great Lakes Res. 16, 143-147.

Meijer, M. L.; de Hann, M. W.; Breukelaar, A. W.; Buiteveld, H., 1990: Is reduction of the benthivorous fish an important cause of high transparency following biomanipulation in shallow lakes? Hydrobiologia 200/201, 303-315.

Mittelbach, G. G.; Persson, L., 1998: The ontogeny of piscivory and its ecological consequences. Can. J. Fish. Aquat. Sci. 55, 1454-1465.

Montaña, C. G.; Layman, C. A.; Winemiller, K. O., 2011: Gape size influences seasonal patterns of piscivore diets in three Neotropical rivers. Neotrop. Ichthyol. 9, 647-655.
Nalepa, T. F.; Quigley, M. A., 1980: The macro- and meiobenthos of southeastern Lake Michigan near the mouth of the Grand River, 1976-77. Great Lakes Environmental Research Laboratory, National Oceanic and Atmospheric Administration data report GLERL-17, Ann Arbor, MI.

Nalepa, T. F.; Wojcik, J. A.; Fanslow, D. L.; Lang, G. A., 1995: Initial colonization of the zebra mussel (Dreissena polymorpha) in Saginaw Bay, Lake Huron: population recruitment, density, and size structure. J. Great Lakes Res. 21, 417-434.

Nalepa, T. F.; Fanslow, D. L.; Lansing, M. B.; Lang, G. A., 2003 Trends in the benthic macroinvertebrate community of Saginaw Bay, Lake Huron, 1987 to 1996: responses to phosphorus abatement and the zebra mussel, Dreissena polymorpha. J. Great Lakes Res. 29, 14-33.

Nelson, P. A.; Dick, T. A., 2002: Factors shaping the parasite communities of trout-perch, Percopsis omiscomaycus Walbaum (Osteichthyes: Percopsidae), and the importance of scale. Can. J. Zool. 80, 1986-1999.

Ogle, D. H.; Selgeby, J. H.; Newman, R. M.; Henry, M. G., 1995: Diet and feeding periodicity of ruffe in the St. Louis River estuary, Lake Superior. Trans. Am. Fish. Soc. 124, 356-369.

Parsons, J. W., 1971: Selective food preferences of walleyes of the 1959 year class in Lake Erie. Trans. Am. Fish. Soc. 100, $474-485$.

Rasband, W. S., 2009: ImageJ, US National Institutes of Health, Bethesda, MD. Available at: http://imagej.nih.gov/ij/ (accessed on 1 July 2011).

Roseman, E. F.; Taylor, W.W, Hayes, D. B.; Hayes, D. B.; Jones, A. L.; Francis, J. T., 2006: Predation on walleye eggs by fish on reefs in western Lake Erie. J. Great Lakes Res. 32, 415 423

Roswell, C. R., 2011:Growth, condition, and diets of age-0 Saginaw Bay yellow perch, implications for recruitment. MS thesis, Purdue University, West Lafayette, IN.

Sibley, C. K., 1929: A biological survey of the Erie-Niagara system, VII. The food of certain fishes of the Lake Erie drainage basin. In: Suppl. to 18th Annual Report, 1928. J. G. Needman, C. Juday, E. Moore, C. K. Sibley and J. W. Titcomb (Ed.) New York Conservation Dept., New York. pp. 180-188.

Smock, L. A., 1980: Relationships between body size and biomass of aquatic insects. Freshwat. Biol. 10, 375-383.

Soetaert, K.; Franco, M.; Lampadariou, N.; Muthumbi, A.; Steyaert, M.; Vandepitte, L.; Vanden Berghe, E.; Vanaverbeke, J., 2009: Factors affecting nematode biomass, length and width from the shelf to the deep sea. Mar. Ecol. Prog. Ser. 392 123-132.

Spafford, M. D., 1999: Trout-perch Percopsis omiscomaycus (Walbaum) and lake chub Couesius plumbeus (Agassiz), as sentinel monitoringsSpecies in the Athabasca River, Alberta. MS Thesis, University of Alberta, Edmonton, AB.

Specziár, A., 2011: Size-dependent prey selection in piscivorous pikeperch Sander lucioperca and Volga pikeperch Sander volgensis shaped by bimodal prey size distribution. J. Fish Biol. 79, 1895-1917.

Swanson, H. K.; Johnston, T. A.; Leggett, W. C.; Bodaly, R. A.; Doucett, R. R.; Cunjak, R. A., 2003: Trophic positions and mercury bioaccumulation in rainbow smelt (Osmerus mordax) and native forage fishes in northwestern Ontario lakes. Ecosystems 6, 289-299.

Vander Zanden, M. J.; Vadeboncoeur, Y., 2002: Fishes as integrators of benthic and pelagic food webs in lakes. Ecology 83, 2152-2161

Author's address: Lori N. Ivan, CILER, University of Michigan, 4840 S. State St. Ann Arbor, MI 48108, USA. E-mail: lori.ivan@noaa.gov 